Development 140, 4296 (2013) doi:10.1242/dev.103184

C) 2013. Published by The Company of Biologists Ltd

\title{
Oesophageal and sternohyal muscle fibres are novel Pax3- dependent migratory somite derivatives essential for ingestion
}

James E. N. Minchin, Victoria C. Williams, Yaniv Hinits, SiewHui Low, Panna Tandon, Chen-Ming Fan, John F. Rawls and Simon M. Hughes

There was an error published in Development 140, 2972-2984.

On p. 2973, $\operatorname{Tg}(m y l z 2: e g f p)$ was incorrectly attributed (Ju et al., 2003). This transgenic fish line was made using the same DNA construct but in the Ingham laboratory (von Hofsten et al., 2008) and has the full name $T g(-2.2 m y l z 2: G F P) i 135$ (see http://zfin.org/action/fish/fishdetail/ZDB-GENO-081119-5,ZDB-GENOX-081230-24).

von Hofsten, J., Elworthy, S., Gilchrist, M. J., Smith, J. C., Wardle, F. C. and Ingham, P. W. (2008). Prdm1- and Sox6-mediated transcriptional repression specifies muscle fibre type in the zebrafish embryo. EMBO Rep. 9, 683-689.

The authors apologise to readers for this mistake. 